\title{
Originals
}

\section{Insulin autoantibodies at the clinical manifestation of Type 1 (insulin-dependent) diabetes - a poor predictor of clinical course and antibody response to exogenous insulin}

\author{
J.Karjalainen ${ }^{1}$, M.Knip ${ }^{1}$, A. Mustonen ${ }^{1}$ and H.K. Åkerblom ${ }^{2}$ \\ ${ }^{1}$ Department of Paediatrics, University of Oulu, Oulu, and \\ ${ }^{2}$ Children's Hospital, II Department of Paediatrics, University of Helsinki, Helsinki, Finland
}

\begin{abstract}
Summary. To study the possible clinical significance of the appearance of insulin autoantibodies prior to the diagnosis of Type 1 (insulin-dependent) diabetes, and their value in predicting the antibody response to exogenous insulin, we observed 46 newly diagnosed diabetic children and adolescents over the year following diagnosis for the occurrence and duration of clinical remission, daily insulin dose, metabolic control, residual B-cell function, insulin-binding antibodies and conventional as well as complement-fixing islet cell antibodies. Insulin-binding antibodies were determined using both monoiodinated human and porcine insulin. Sixteen children (34.7\%) were positive for insulin autoantibodies upon diagnosis of Type 1 diabetes. These subjects were significantly younger $(6.2 \pm 1.0$ versus $10.8 \pm 0.8$ years; mean \pm SEM, $p<0.001$ ), and their haemoglobin $\mathrm{A}_{1}$ levels were lower $(14.1 \pm 0.6$ versus $16.0 \pm 0.8 \%, p<0.05)$ at diagnosis than in the insulin autoantibody negative group. There were no significant differences in the occurrence and duration of clinical remission between insulin autoantibody-positive and -negative test groups. Daily insulin dose, haemoglobin $A_{1}$ and serum C-peptide concentrations were of the same magnitude in both groups after the diagnosis, and no association could be
\end{abstract}

found between the presence of insulin autoantibodies at diagnosis and persistently positive islet cell antibodies. In tests conducted 3 months after diagnosis, the group of patients with insulin autoantibodies showed significantly higher levels $(p<0.05)$ of antibodies binding human insulin than the group negative for insulin autoantibodies, but no significant differences could be found between the insulin binding titres of the two groups in subsequent analyses. Those who were still positive for conventional islet cell antibodies one year after diagnosis had significantly higher levels of antibodies binding human insulin $(34.6 \pm 6.1$ versus $12.9 \pm 1.7 \%, p<$ $0.05)$ as well as antibodies binding porcine insulin (33.0 \pm 5.9 versus $12.7 \pm 2.9 \%, p<0.05$ ) than the other subjects. Our observations suggest that insulin autoantibodies developing before the diagnosis of Type 1 diabetes have no influence on the clinical course of the disease over the first year following diagnosis, and they appear to serve as a poor predictor of the antibody response to insulin treatment.

Key words: Type 1 (insulin-dependent) diabetes, insulin autoantibodies, islet cell antibodies, metabolic control, C-peptide, clinical remission.
The presence of circulating autoantibodies to insulin in subjects with newly diagnosed Type 1 (insulin-dependent) diabetes has been confirmed in several studies [1-5]. The possible role of these insulin autoantibodies (IAA) in the pathogenesis and natural course of the disease is still uncertain, although it has been suggested that they serve, like islet cell antibodies (ICA), as serum markers for autoimmune B-cell damage [2,3]. In a previous study [5], we found no relation between IAA and either conventional (ICA-IgG) or complement-fixing ICA (CF-ICA). There was, however, an association between IAA and young age at diagnosis, as well as with HLA-antigen Dw4. To study whether IAA detected at the diagnosis of Type 1 diabetes exert any influence on the clinical course of the disease or predict the antibody response to exogenous insulin, we have observed a group of newly diagnosed diabetic children and adolescents for the initial 12 months after diagnosis for the occurrence and duration of clinical remission, daily insulin dose, residual B-cell function, metabolic control, insulin-binding antibodies (IBA) and both ICA-IgG and CF-ICA.

\section{Subjects and methods}

The study comprised 46 diabetic children and adolescents (20 boys) who were admitted to the Department of Paediatrics, University of Oulu, between February 1982 and March 1985 for the initial treatment of classic acute-onset Type 1 diabetes. Their mean age at diagnosis was $8.9 \pm 0.6$ (SEM) years (range 1.3 15.8 years), and the mean 
duration of their symptoms before diagnosis was $5.1 \pm 0.7$ weeks (range 1-20). At admission, 16 of the patients had no ketosis (group I) or acidosis, 14 were ketotic without acidosis (group II) and 16 had ketoacidosis (group III). The mean blood glucose concentration at presentation was $19.0 \pm 2.4(\mathrm{SEM}) \mathrm{mmol} / \mathrm{l}$ in group I, $19.9 \pm$ $1.8 \mathrm{mmol} / 1$ in group II and $23.5 \pm 3.4 \mathrm{mmol} / 1$ in group III, whereas the mean serum C-peptide level was $0.21 \pm 0.05 \mathrm{nmol} / 1$ in group I, $0.15 \pm 0.02 \mathrm{nmol} / 1$ in group II and $0.21 \pm 0.05 \mathrm{nmol} / 1$ in group III. Accordingly, also the patients without ketosis and acidosis (group I) had low serum C-peptide concentrations in spite of considerable hyperglycaemia.

Insulin treatment was initiated with either intravenous infusion of short-acting insulin in ketoacidotic patients, or by the use of subcutaneous short-acting insulin injections to correct the metabolic derangement within 1-3 days. The subsequent treatment aimed at optimal metabolic control and subjective well-being. Clinical remission was defined as a period which occurs shortly after the diagnosis of diabetes when the daily insulin dose is less than $0.5 \mathrm{U} / \mathrm{kg}$ body weight and glycosylated haemoglobin $\mathrm{A}_{1}$ lower than $9.2 \%$ (mean $+3 \mathrm{SD}$ in nondiabetic subjects) and which lasts for at least one month. All the patients were regularly seen in the Diabetes Clinic at intervals of $1-3$ months. The first 39 patients were treated with highly purified porcine insulins (MC Monotard and Actrapid, Novo A/S, Bagsvaerd, Denmark or R. I. Insulatard and Velosulin, Nordisk Insulinlaboratorium, Gentofte, Denmark), and the last 7 children with human insulins (MC Protaphan and MC Actrapid Human, Novo $\mathrm{A} / \mathrm{S}$ ). The first blood sample was taken before the commencement of insulin treatment and subsequent specimens were obtained at 3-month invervals during each patient's visit to the Diabetes Clinic. The samples were taken after lunch, between 12.00 and 14.00 hours. The C-peptide concentrations in these postprandial samples were considered as reflecting the residual B-cell function, since we have observed a strong correlation between randomly sampled postprandial C-peptide levels and serum C-peptide concentrations, measured $60 \mathrm{~min}$ after a standardised breakfast $(r=0.73, p<$ $0.001)$, and 24-h urinary C-peptide excretion $(r=0.83, p<0.001)$ in a series including 32 diabetic children and adolescents (unpublished data). The timing of blood sampling had no effect on the insulin binding measurements, since we have analysed the insulin binding in serum samples from 10 patients at three different time points $(7.00$, 12.00 and 14.00 hours) and observed no significant differences in the percent human insulin bound $(12.9 \pm 4.3 \%$ (SEM) versus $12.3 \pm 4.1 \%$ versus $12.2 \pm 4.2 \%$ ).

Both IAA and subsequent IBA were determined by a modification of the liquid phase radioimmunoassay originally described by Palmer et al. [1] in 1983. They have shown that the insulin binding protein is precipitated by an antibody against immunoglobulin $G$ and is eluted from a gel filtration column at the same position as gamma globulin. The serum samples were extracted with acid charcoal before the assay as described by Srikanta et al. [6] to remove endogenous insulin. To evaluate the effect of the acid ethanol extraction on the results we compared the insulin binding in unextracted and extracted portions of samples from 15 patients. In our hands the extraction procedure increased the insulin binding significantly from a mean of $1.6 \pm 0.3 \%$ (SEM) in unextracted samples to $5.3 \pm 1.1 \%$ $(p<0.01)$ in charcoal treated samples. There was a significant correlation between the insulin binding levels in the extracted and unextracted samples $(r=0.90 ; p<0.001)$. In the assay $80 \mu \mathrm{l}$ of the extracted serum were incubated with mono- ${ }^{125} \mathrm{I}$ (Tyr A 14)-human insulin or mono- ${ }^{125} \mathrm{I}$ - (Tyr A 14) porcine insulin (specific activity $200-300 \mathrm{mCi}$ / $\mathrm{mg}$; Novo Research Institute, Bagsvaerd, Denmark) for $20 \mathrm{~h}$. Free and bound insulin fractions were separated using polyethylene glycol. Results were expressed as the percentage of bound radioactivity in the precipitate out of the total counts in the assay (approximately $20,000 \mathrm{cpm} /$ tube). The mean non-specific binding, i. e. the binding in the presence of an excess of unlabelled insulin $\left(10^{5} \mathrm{ng} / \mathrm{ml}\right)$ was found to be $0.6 \%$ in 10 samples with an inconsiderable variation (range $0.6-0.7 \%$ ). The results were not corrected for nonspecific binding. Figure 1 shows the displacement of mono- ${ }^{-125}$ I (Tyr A 14)human insulin by increasing concentrations of unlabelled human in-

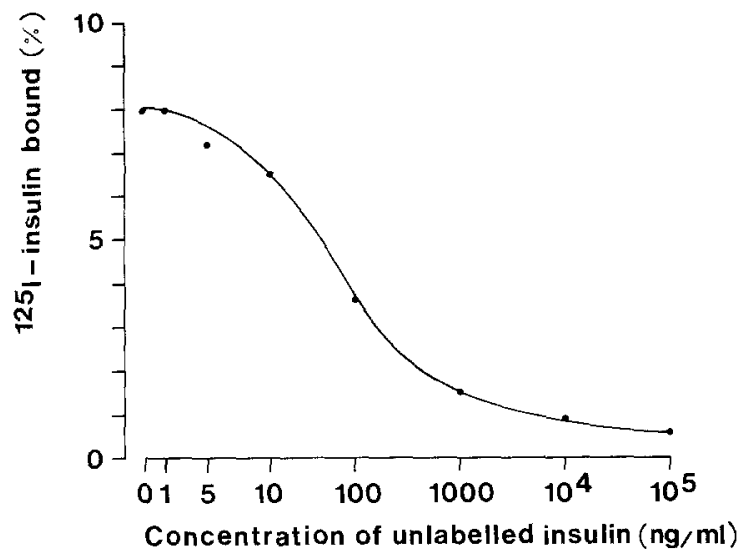

Fig. 1. Displacement of ${ }^{125} \mathrm{I}$-insulin by unlabelled insulin in a sample from a newly diagnosed Type 1 (insulin-dependent) diabetic patient positive for insulin autoantibodies

sulin in a sample from a patient with newly diagnosed diabetes. The intra-assay coefficient of variation was lower than $5 \%$ and the interassay coefficient of variation lower than $8 \%$. The binding of monoiodinated human insulin was $1.54 \pm 0.29 \%$ (mean \pm SD) in 68 nondiabetic children with a range from 0.6 to $2.8 \%$, whereas that of monoiodinated porcine insulin was $1.80 \pm 0.36 \%$ (range $0.8-3.0 \%$ ). There was a strong correlation between the binding of human insulin and that of porcine insulin in the nondiabetic children $(r=0.99, p<$ 0.001 ). The diabetic children with a binding of monoiodinated human insulin exceeding $2.8 \%$ (corresponding $4.3 \mathrm{SD}$ above the mean in 68 control subjects) at diagnosis were considered to be positive for insulin autoantibodies (IAA). The human insulin tracer was chosen as an indicator for positive IAA, since human insulin in one form or another induces the formation of IAA.

ICA were determined by immunofluorescence using both the conventional indirect method (ICA-IgG) and the complement-fixation technique (CF-ICA) [7]. Fluorescein-conjugated rabbit antihuman-IgG and $-\mathrm{C}_{3} \mathrm{c}$ diluted to 1:40 were used for detection of ICA. Blood group 0 human pancreas was used as a substrate. To evaluate the method for measuring ICA, samples from 20 subjects were studied 6-7 times repeatedly on a "blind" basis. The reproducibility proved to be good with no overlapping between positive and negative samples. Serum-C-peptide concentrations were measured by radioimmunoassay using antiserum M 1230 (Novo Research Institute) as previously described [8]. Haemoglobin $\mathrm{A}_{1}$-levels were determined electrophoretically [9] with a reference range of $5.5-8.4 \%$ in nondiabetic subjects.

\section{Statistical analysis}

The statistical evaluation was performed by: (1) crosstabulation and chi-square-statistics; (2) the parametric one-way analysis of variance, the unpaired Student's t-test and linear regression analysis, $(r)$, in the case of normally distributed variables; and otherwise, (3) the Mann-Whitney U-test and Spearman rank correlation analysis $\left(r_{\mathrm{s}}\right)$. The analysis of co-variance was carried out to exclude the effects of age on the results. The results are expressed as mean $\pm S E M$ if not indicated otherwise.

\section{Results}

There was no significant difference at diagnosis between the insulin binding measured with the human insulin tracer and that obtained with the porcine tracer (Fig. 2). Sixteen out of the 46 diabetic children (34.7\%) 


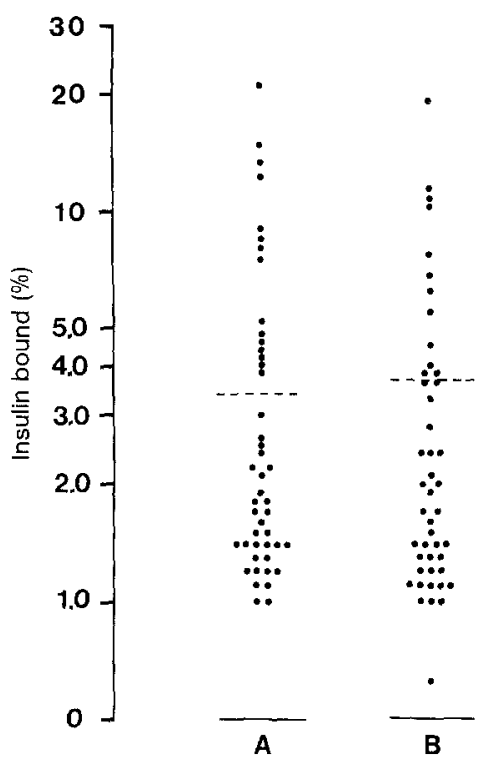

Fig. 2. Binding of mono- ${ }^{125} 1$ (Tyr A 14)-human and porcine insulin in sera of 46 subjects with newly diagnosed Type 1 diabetes before the start of insulin treatment. A represents the binding of human insulin and $\mathbf{B}$ that of porcine insulin. Broken lines = mean values

Table 1. The duration of clinical remission, as well as insulin dose, haemoglobin $\mathrm{A}_{1}$, serum $\mathrm{C}$-peptide concentrations, levels of pIBA, mean $\pm S E M$, and the frequency of persistent ICA-positivity at 12 months after diagnosis of Type 1 (insulin-dependent) diabetes in 46 diabetic children, classified on the basis of the presence of IAA at diagnosis

\begin{tabular}{llll}
\hline & $\begin{array}{l}\text { IAA+ } \\
(n=16)\end{array}$ & $\begin{array}{l}\text { IAA- } \\
(n=30)\end{array}$ & $\begin{array}{l}\text { Level of } \\
\text { significance }\end{array}$ \\
\hline $\begin{array}{l}\text { Duration of } \\
\text { remission (days) }\end{array}$ & $118 \pm 38$ & $115 \pm 38$ & $\mathrm{NS}$ \\
$\begin{array}{l}\text { Insulin dose (U/kg) } \\
\begin{array}{l}\text { Glycosylated } \\
\text { haemoglobin A }(\%)\end{array}\end{array}$ & $0.49 \pm 0.05$ & $0.51 \pm 0.03$ & $\mathrm{NS}$ \\
$\begin{array}{l}\text { Serum C-peptide } \\
\text { (nmol/l) }\end{array}$ & $0.15 \pm 0.03$ & $0.23 \pm 0.05$ & $\mathrm{NS}$ \\
$\begin{array}{l}\text { pIBA (\%) } \\
\text { Persistently ICA-IgG- } \\
\text { positive, } n(\%)\end{array}$ & $\begin{array}{l}32.4 \pm 25.7 \\
\text { Persistently CF-ICA- } \\
\text { positive, } n(\%)\end{array}$ & $21.1 \pm 20.6$ & $\mathrm{NS}$ \\
\hline
\end{tabular}

IAA $=$ insulin autoantibodies, pIBA $=$ percentage of antibodies binding porcine insulin, ICA-IgG $=$ conventional islet-cell antibodies, $\mathrm{CF}-\mathrm{ICA}=$ complement-fixing islet-cell antibodies, $\mathrm{NS}=$ not significant

had IAA in their sera. The distribution of IAA positive subjects was similar among subjects treated with human insulin as compared to those on porcine insulin. The mean binding of human insulin in their serum was $8.4 \pm 1.3 \%$. The IAA positive children were younger at diagnosis of the disease $(6.2 \pm 1.0$ versus $10.8 \pm$ 0.8 years, $p<0.001$ ) than the other subjects. Six $(37.5 \%)$ out of the 16 IAA positive patients and 18 $(60 \%)$ out of the 30 IAA negative patients experienced a remission period. There was no significant difference in the remission frequency between the two groups,

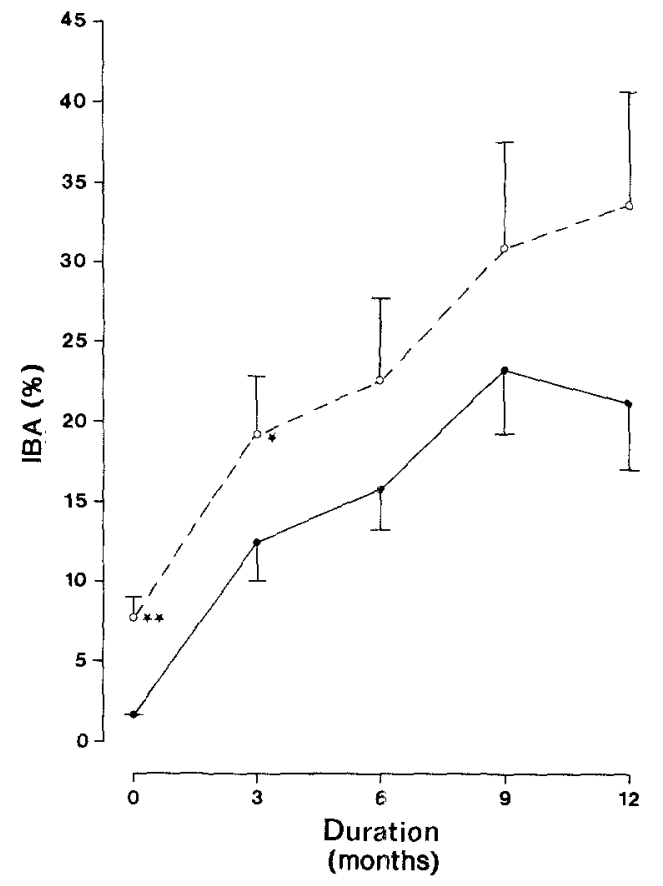

Fig. 3. Titres of antibodies binding human insulin (hIBA), mean \pm SEM, over the first 12 months after diagnosis of Type 1 diabetes in 16 children initially positive for insulin autoantibodies $(O \ldots O)$ and in 30 antibody negative children $(-)$ ). ${ }^{*} p<0.05$ and ${ }^{* *} p<$ 0.001

nor could we find any difference in the duration of the clinical remission (Table 1). The daily insulin dose was of the same magnitude in both groups throughout the first year. The IAA negative patients had a lower level of haemoglobin $A_{1}$ at diagnosis $(14.1 \pm 0.6 \%$ versus $16.0 \pm 0.8 \%, p<0.05)$ than the IAA positive patients, though, later on, haemoglobin $A_{1}$ values did not differ between the two groups. The serum C-peptide concentrations in the IAA positive children did not differ significantly from those in the IAA negative ones at any time during the observation period.

Thirty-five children $(76.1 \%)$ were positive for ICA$\mathrm{IgG}$ at diagnosis and $23(50 \%)$ remained positive over the first year. At the end of the observation period these children had significantly higher titres of antibodies binding human insulin (hIBA; $34.6 \pm 6.1 \%$ versus $12.9 \pm 1.7 \%, p<0.05$ ) as well as porcine insulin (pIBA; $33.0 \pm 5.9 \%$ versus $12.7 \pm 2.9 \%, p<0.05$ ) than the other subjects. CF-ICA were found in 31 patients $(67.4 \%)$ at the clinical manifestation, and 10 children (21.7\%) were still positive 12 months later. Among the 16 IAA positive patients at diagnosis ICA-IgG as well as CF-ICA were detected in 11 patients. Neither the 5 IAA positive (but ICA negative) patients nor those 24 patients positive for ICA but negative for IAA differed at diagnosis from other patients in any clinical or biochemical aspect. No association could be observed between CF-ICA on one hand and IAA, hIBA or pIBA on the other.

The IAA positive patients had significantly higher levels of hIBA than the IAA negative children (Fig.3) 
3 months after diagnosis. During the following 9 months no significant differences could be detected in the titres of IBA between the two groups, although the mean level of IBA decreased in the IAA negative patients during the last months, while the increasing trend continued in the IAA positive children. In addition, the increase in the IBA-titres over the first year was similar in the IAA negative subjects $(21.6 \pm 3.6 \%$, range $1.3-85.3 \%$ ) and the IAA positive subjects $(33.1 \pm 6.3 \%$, range $3.4-85.3 \%)$. In all 46 patients there was a positive correlation between the levels of IAA at diagnosis and the titres of hIBA at 3 months $\left(r_{\mathrm{s}}=0.38\right.$; $p<0.05$ ), but later on, no significant relation could be found between IAA and hIBA or pIBA $\left(r_{\mathrm{s}}=0.20-0.26\right.$; $p=0.07-0.18$ ). The predictive value of the IAA present at diagnosis of Type 1 diabetes therefore seems to be low in view of the subsequent antibody response to exogenous insulin. There was a good correlation between the levels of hIBA and pIBA in the diabetic patients at different points during the observation period $(r=0.91-0.97, p<0.0001)$. No significant difference could be shown on any occasion between the hIBA and pIBA titres. On the other hand there was an inverse relation between the IBA-levels and age at diagnosis at different time points (3,9 and 12 months) after diagnosis $(r=-0.38, p<0.01 ; r=-0.26, p<0.05$; $r=-0.33, p<0.02)$. We found no significant differences in the IBA titres at any time point or in the increase of the titres over the first year between the subjects on porcine insulin and those treated with human insulin.

\section{Discussion}

IAA have been demonstrated in $16-38 \%$ of subjects with newly diagnosed Type 1 diabetes [1-5]. In addition, IAA have been found in a considerable number of monozygotic twins discordant for the Type 1 diabetes $[2,6]$, and in other groups at high risk for developing the disease [6]. The possible association between IAA and ICA, which are considered to be markers of ongoing autoimmune mechanism-mediated B-cell destruction [10-13], is controversial. Bergman et al. [4] reported an increased incidence of IAA among newly diagnosed diabetic patients with conventional ICA. Srikanta et al. [6] found a positive association between IAA and ICA-IgG in a highly selected group of subjects at enhanced risk for developing the disease. Furthermore, they concluded that the simultaneous presence of IAA and ICA-IgG in such high risk individuals results in a substantially higher incidence of progression to the disease than the isolated occurrence of either marker alone. There are, however, several reports indicating a lack of association between IAA and ICA-IgG $[2,3,5]$ as well as CF-ICA [5]. The present study provides further evidence of a dissociation between IAA and ICA in newly diagnosed diabetic pat- ients. In addition, we could not find any relation between the presence of IAA at diagnosis and persistent ICA-IgG- or CF-ICA-positivity over the following year. Our observations support the view presented by Srikanta et al. [6] that IAA and ICA are either markers of, or the consequence of, differences in the immunologic destructive processes of the $B$ cells. The finding of higher IBA levels at 12 months after diagnosis in those patients still positive for ICA-IgG needs confirmation.

Based on the present results, the appearance of IAA before the diagnosis of Type 1 diabetes seemed to have had no effect on the clinical course of the newly diagnosed disease. We found no differences between the IAA positive and negative subjects in the incidence and duration of clinical remission, in the amount of exogenous insulin required, or in metabolic control and endogenous insulin secretion at any point during the initial 12 months after diagnosis. The insulin antibodies which develop in response to exogenous insulin during the first few years may have a deletorious effect on the residual B-cell function $[14,15]$. Our findings suggest that the residual $\mathrm{B}$-cell function is unrelated to the development of IAA before diagnosis.

Children with diabetes are more prone to produce antibodies to exogenous insulin than adults [16]. Young children form, in addition, more antibodies than older ones in response to insulin therapy [15] as confirmed in the present study by the inverse association between the age at clinical manifestation and subsequent IBA-levels. On the basis of these observations, and due to a recent finding of an inverse relation between IAA and the age of the patients at the time of diagnosis [3], with several confirmations [4-6] reported thereafter, we speculated that the pre-diagnostic IAA may be related to the subsequent formation of antibodies to exogenous insulin. The present study shows, however, that the presence of IAA at the time of diagnosis of Type 1 diabetes is a poor predictor of the antibody response to insulin administration, since the increase in the levels of hIBA as well as pIBA were of the same magnitude in both the IAA positive and negative subjects. The IAA positive diabetic patients had significantly higher titres of hIBA than the IAA negative individuals only 3 months after the diagnosis of the disease. Accordingly, the IAA formed before diagnosis do not appear to be a useful indicator of the subsequent antibody response to exogenous insulin. This finding is in agreement with the preliminary results of another group [17].

In conclusion, we have shown that the IAA developing before the diagnosis of Type 1 diabetes appear to have neither any positive nor negative effect on the clinical course over the first year of manifest disease. In addition, these antibodies are poor predictors of the antibody response to insulin therapy. The IAA seem to be serologic markers of autoimmune B-cell damage, unrelated to either ICA-IgG or CF-ICA. Their most 
important role may be in the identification of individuals at high risk for contracting Type 1 diabetes.

Acknowledgements. We thank Ms. T.Halonen and Ms. S. Anttila for their skillful technical assistance. The study was supported by the Alma and K.A.Snellman Foundation, Oulu, Finland (J. K.), the Foundation for Diabetes Research in Finland (J.K.) and Novo Research Institute (M.K.), Bagsvaerd, Denmark.

\section{References}

1. Palmer JP, Asplin CM, Clemons P, Lyen K, Tatpati O, Raghu PK, Paquette TL (1983) Insulin antibodies in insulin-dependent diabetics before insulin treatment. Science 222: 1337-1339

2. Wilkin T, Hoskins PJ, Armitage M, Rodier M, Casey C, Diaz J-L, Pyke DA, Leslie RDG (1985) Value of insulin autoantibodies as serum markers for insulin-dependent diabetes mellitus. Lancet I: $480-482$

3. Arslanian SA, Becker DJ, Rabin B, Atchison R, Eberhardt M, Cavender D, Dorman J, Drash AL (1985) Correlates of insulin antibodies in newly diagnosed children with insulin-dependent diabetes before insulin therapy. Diabetes 34: 926-930

4. Bergman S, Ludvigsson J, Binder C, Mandrup-Poulsen T (1985) Insulin antibodies before treatment in ICA-positive children with IDDM. Diabetes Res Clin Pract [Suppl] 1: 45

5. Karjalainen J, Knip M, Mustonen A, Ilonen J, Åkerblom HK (1986) Relation between insulin antibody and complement-fixing islet cell antibody at clinical diagnosis of IDDM. Diabetes 35: 620-622

6. Srikanta S, Ricker AT, McCulloch DK, Soeldner JS, Eisenbarth GS, Palmer JP (1986) Autoimmunity to insulin, beta cell dysfunction, and development of insulin-dependent diabetes mellitus. Diabetes 35: 139-142

7. Bottazzo GF, Dean BM, Gorsuch AN, Cudworth AG, Doniach D (1980) Complement-fixing islet-cell antibodies in type I diabetes: possible monitors of active beta cell damage. Lancet I: 668-672

8. Heding LG (1975) Radioimmunological determination of human C-peptide in serum. Diabetologia 11: $541-548$

9. Puukka R, Leppilampi M (1982) Electrophoretically determined hemoglobin $\mathrm{A}_{1}$ concentrations during short-term changes in glucose concentrations. Ann Clin Biochem 19: 350-353

10. Ilonen J, Mustonen A, Åkerblom HK, Huttunen N-P (1980) Complement-fixing islet-cell antibodies before and after onset of insulin-dependent diabetes. Lancet II: 805

11. Gorsuch AN, Spencer RM, Lister J, Wolf E, Bottazzo GF, Cudworth AG (1982) Can future type I diabetes be predicted? A study in families of affected children. Diabetes 31: 862-866

12. Mustonen A, Knip M, Åkerblom HK (1983) An association between complement-fixing cytoplasmic islet-cell antibodies and endogenous insulin secretion in children with insulin-dependent diabetes mellitus. Diabetes 32: 743-747

13. Mustonen A, Knip M, Huttunen N-P, Puukka R, Käär M-L, Åkerblom HK (1984) Evidence of delayed beta-cell destruction in type I (insulin-dependent) diabetic patients with persisting complement-fixing cytoplasmic islet-cell antibodies. Diabetologia 27: 421-426

14. Ludvigsson $J$ (1984) Insulin antibodies in diabetic children treated with monocomponent porcine insulin from the onset: Relationship to B-cell function and partial remission. Diabetologia 26: 138-141

15. Mäkelä A-L, Åkerblom HK, Käär M-L, Heding LG, Knip M, Mäkelä $P(1985)$ Insulin antibodies in diabetic children related to the age of patients and serum C-peptide values. Two years' follow-up results of a randomized study. Diabetes Res Clin Pract [Suppl] 1: 255

16. Ákerblom HK, Mäkelä A-L (1977) Insulin antibodies in the serum of diabetic children treated from the diagnosis of the disease with highly purified insulins. Acta Paediatr Scand [Suppl] 270: $69-79$

17. Ludvigsson J, Binder C (1985) Amount of insulin antibodies after insulin treatment is not related to insulin autoantibodies at onset of IDDM. Diabetes Res Clin Pract [Suppl] 1: 348

Received: 11 June 1987

and in revised form: 31 December 1987

Dr. Jukka Karjalainen

Department of Paediatrics

University of Oulu

SF-90220 Oulu

Finland 